\section{Genetic parameters and selection of sugarcane for borer resistance in the advanced selection stage}

\begin{abstract}
This study aimed to investigate genetic parameters and selection strategies for sugarcane resistance to borer and determine the effects of selection for borer resistance on yield traits. The infestation index by borer (IIB) and yield traits were assessed over 3 years in 35 sugarcane clones planted in four locations in southeastern Brazil. There was no genotype $x$ environment (year or location) interaction for borer resistance. Consequently, selection may be performed at only one location and year or by the mean of clones in several locations and/or years. The borer population affected the genotypic variance for borer resistance but when genotypic variance was significant, heritability was elevated and suitable genetic gain was achieved. Selection for borer resistance reduced the genetic gains for tons of cane per hectare, theoretical recoverable sugar, and tons of sugar per hectare; however, satisfactory selection gains for both borer resistance and yield were achieved using selection index.
\end{abstract}

Keywords: Saccharum spp., Diatraea saccharalis, genotype $\times$ environment interaction.

\section{INTRODUCTION}

Brazil is the world's largest sugarcane producer. The sugarcane crop area in the country covers nearly 8.38 million hectares and sugarcane production during the $2019 / 20$ agricultural year is estimated at 622.3 million tons. It is estimated that sugar production will reach 31.8 million tons and ethanol production 30.3 billion liters (CONAB 2019)

The sugarcane stalk borer Diatraea saccharalis Fab. (Lepidoptera: Crambidae) is one of the major pests of sugarcane in Brazil and causes severe yield losses across the country (Francischini et al. 2017). The larvae open galleries in the stalks, reducing sugar content and stalk weight. In addition, it enables the entrance of fungus that causes red rot disease, which reduces both sugar yield and quality (Tomaz et al. 2017). This pest is managed using biological control with larval endoparasitoid Cotesia flavipes and egg parasitoid Trichogramma galloi. However, the use of chemical insecticides has increased (Simões et al. 2015, Valente et al. 2018).

The use of sugarcane varieties resistant to this pest is an important tool for Integrated Pest Management (IPM), enabling reduced environmental impacts, production costs, and yield losses (Milligan et al. 2003). Currently, transgenic sugarcane varieties resistant to $D$. saccharalis containing genes from Bacillus
Crop Breeding and Applied Biotechnology 20(1): e290620113, 2020 Brazilian Society of Plant Breeding. Printed in Brazil http://dx.doi.org/10.1590/1984-

\author{
Adriano Cirino Tomaz ${ }^{1 *}$, Mateus Teles Vital Gonçalves ${ }^{2}$, Marcos \\ Deon Vilela de Resende ${ }^{2}$, Bruno Portela Brasileiro ${ }^{3}$, Luiz \\ Alexandre Peternelli² and Márcio Henrique Pereira Barbosa ${ }^{2}$
} \\ 70332020v20n1a13

(20) 
thuringiensis bacteria ( $B t$ ) have been released in Brazil (MAPA 2019). However, there is the possibility of the rapid evolution of sugarcane borer resistance to Bt proteins under large-scale field use (Girón-Pérez et al. 2014, Cristofoletti et al. 2018). The development of sugarcane genotypes resistant to the borer through conventional breeding could enable more durable resistance and could be performed in sugarcane breeding programs with no access to transgenic technologies.

Several resistance mechanisms against the sugarcane borer have been reported in sugarcane genotypes, including a low preference for oviposition, high mortality of early-instar larvae, the difficulty of larvae entering the stalks, and lower larvae development within the stalks (Pimentel et al. 2017, Tomaz et al. 2017). In addition, differences among genotypes are often reported in field trials for several resistance traits, such as the percentage of bored internodes or internodes with exit holes, percentage of bored stalks, pupation success, estimates of adults produced per area/year/ variety, and the damage rating (Bessin et al. 1990, White 1993, White et al. 2011, Milligan et al. 2003, Nibouche and Tibere 2008, Nikpay 2016). Among these traits, the percentage of bored internodes (or infestation index) is the most effective trait for the prediction of yield losses (Milligan et al. 2003) and it is often assessed in sugarcane populations as an indication of the resistance level of the genotypes.

The study of genetic parameters in the populations is essential to determining the appropriate selection strategies when breeding for quantitative traits, such as borer resistance (White et al. 2001, Milligan et al. 2003). These parameters include genotypic variance, heritability, genotype $\times$ environment (location and year) interactions, and genetic correlation among traits. These parameters have been extensively studied in Brazil for several sugarcane traits, such as tons of cane per hectare (TCH) (Veríssimo et al. 2012), tons of Brix per hectare (TBH) (Bastos et al. 2007, Veríssimo et al. 2012), and tons of sugar per hectare (TSH) (Silveira et al. 2012). However, only a few studies regarding the genetic parameters for the resistance of sugarcane to borers, such as D. saccharalis and spotted borer Chilo sacchariphagus (Lepidoptera: Pyralidae), have been reported (White et al. 2001, Milligan et al. 2003, Nibouche and Tibere 2008, Tomaz et al. 2019). In addition, there is a need for studies regarding selection for borer resistance, in addition, to yield traits, because selection only for borer resistance may result in genotypes with unfavorable traits and lower sugar yield (White et al. 2006, White et al. 2011).

The lack of knowledge regarding genetic parameters of Brazilian sugarcane populations and selection strategies hinders the selection of resistance genotypes by Brazilian sugarcane breeding programs. Therefore, the goals of this study were to estimate genetic parameters (genotypic variance, heritability), assess the influence of the genotype $\times$ environment interaction in borer resistance, determine the effects of selection for borer resistance on yield traits, and compare selection strategies for borer resistance at several locations, across years, and for borer resistance in addition to yield traits.

\section{MATERIAL AND METHODS}

\section{Plant material and experimental design}

The genotypes used in this study compose the advanced stage or experimental stage of the sugarcane breeding program of the Universidade Federal de Viçosa, in partnership with RIDESA (Inter-university Network for the Development of Sugarcane Industry) (Gazaffi et al. 2016). The experiments were conducted on farms of RIDESA's partner mills in four locations: Iturama, Itapagipe, Ituiutaba, and Tupaciguara counties, Minas Gerais state, southeastern Brazil. Planting of sugarcane clones was conducted between April-May 2013. Soil fertilization, crop management, and harvest were performed according to procedures established and adopted by the growers. Each experiment was composed of two commercial sugarcane varieties (checks) and the genotypes selected in the previous selection stage (T3) by RIDESA's sugarcane breeding program. The experimental information on the number of genotypes, blocks, and plot sizes for each experiment are summarized in Table 1. The total number of genotypes used in all experiments was 35 . The genotypes were not planted in all locations because of the lack of propagation material and restricted field area. However, most genotypes were repeated in at least two locations.

\section{Data collection}

For assessment of borer damage, 20 whole stalks per plot were randomly selected and harvested. Stalks were split longitudinally and the number of total internodes and bored internodes were recorded to calculate the infestation index (IIB) by borer with the formula: 
Genetic parameters and selection of sugarcane for borer resistance in the advanced selection stage

Table 1. Number of genotypes and blocks, plot size, and years of assessment in the experimental net for sugarcane resistance to the borer

\begin{tabular}{|c|c|c|c|c|c|}
\hline Locations & Genotypes & Blocks & Plots & Assessments & Checks \\
\hline Itapagipe & 18 & 4 & 4 rows $(19 \times 1.5 \mathrm{~m})$ & 2015,2016 & RB867515, RB966928 \\
\hline Iturama & 18 & 5 & 5 rows $(5 \times 1.5 \mathrm{~m})$ & 2015, 2016, 2017 & RB867515, CTC9 \\
\hline Ituiutaba & 24 & 4 & 4 rows $(19 \times 1.5 \mathrm{~m})$ & 2015 & RB867515, CTC9 \\
\hline Tupaciguara & 24 & 5 & 5 rows $(5 \times 1.5 \mathrm{~m})$ & 2016, 2017 & RB867515, RB855453 \\
\hline \multicolumn{6}{|c|}{ Genotypes (number of locations) } \\
\hline RB855453 (1) & RB057246 (1) & RB047025 (2) & RB057249 (3) & RB047212 (3) & RB867515 (4) \\
\hline RB047210 (1) & RB057235 (1) & RB057267 (2) & RB047055 (3) & RB057270 (3) & RB047248 (4) \\
\hline RB047228 (1) & RB057237 (1) & RB047412 (2) & RB047050 (3) & RB057231 (3) & RB047409 (4) \\
\hline RB057008 (1) & CTC9 (2) & RB057169 (2) & RB047201 (3) & RB057145 (4) & \\
\hline
\end{tabular}

IIB $=\left(\frac{\text { number of bored internodes }}{\text { total number of internodes }}\right) \times 100$ (White et al. 2011). The assessments of borer damage were performed in July 2015, July 2016, and July 2017, respectively, for the first, second, and third ratoon crops.

Because of the likely genotype $\times$ location interaction for yield traits (Veríssimo et al. 2012, Silveira et al. 2012), the study of selection for borer resistance in addition to that of yield traits was performed at only one location. For this study, the theoretical recoverable sugar (TRS), TCH, and TSH were assessed in the experiment in Iturama during the agricultural years of 2015, 2016, and 2017. The number of stalks per meter and the mean weight of the stalks were assessed for TCH determination. Ten stalks per plot were weighed to estimate the mean weight of the stalks. Then, the stalks were taken to the lab of the sugar and alcohol industry for the determination of TRS. The TCH was estimated by the formula:

$\mathrm{TCH}=\frac{\text { number of stalks per meter } \times \text { mean weight of stalk } \times 10000}{1.5}$

The TRS was estimated according to standard procedures used by the mills (Consecana 2006).

\section{Data analysis}

Genetic parameters and comparison of selection scenarios for borer resistance

The data for the infestation index were analyzed together using mixed models with the software Selegen-Restricted Maximum Likelihood (REML)/Best Linear Unbiased Predictors (BLUP) (Resende 2016). The data on the infestation index by $D$. saccharalis were analyzed considering four selection scenarios: single experiments, one location over 3 years, three locations in 1 year, and four locations over 3 years. The genetic parameters were estimated using the REML method. The significance of the effects (i.e., genotypic variance, genotype $\times$ location interaction) was analyzed by deviance analysis (Likelihood Ratio Test) and the genotypic values were estimated by the BLUP (Resende 2016).

The genotypic values within every single experiment were estimated using the model:

$$
y=X r+Z g+e
$$

where, $y$ is the vector of phenotypic data, $r$ is the vector of fixed block effects, $g$ is the random effect of genotypes, and $e$ is the vector of error. The capital letters represent the incidence matrix for the referred effects in the model described above and follow the models described below.

The genotypic values in one location (Iturama) over three years $(2015,2016$, and 2017) were estimated by using the model:

$$
y=X m+Z g+W p+T i+e
$$

where, $y$ is the vector of phenotypic data, $m$ is the vector of fixed effects of the year-block combination, $g$ is the vector of random effects of genotypes, $p$ is the vector of random effects of the environment or plot, $i$ is the vector of the random interaction of genotype $\times$ year and $e$ is the vector of error. 


\section{AC Tomaz et al.}

The genotypic values in three locations (Iturama, Ituiutaba, and Itapagipe) and one year (2015) were estimated by using the model:

$$
y=X r+Z g+W i+e
$$

where, $y$ is the vector of phenotypic data, $r$ is the vector of fixed block effects, $g$ is the vector of random effects of genotypes, $i$ is the vector of the random interaction of genotype $\times$ location, and $e$ is the vector of error.

The genotypic values for selection in four locations over 3 years (Iturama, Itapagipe, and Ituiutaba in 2015, Iturama, Itapagipe, and Tupaciguara in 2016, and Iturama and Tupaciguara in 2017) were estimated by the model:

$$
y=X f+Z g+Q g l+T g m+W g m l+S p+e
$$

where, $y$ is the vector of phenotypic data, $f$ is the vector of fixed effects of the block-location-year combination, $g$ is the vector of random effects of genotypes, $g /$ is the vector of the random effects of interaction of genotype $\times$ location, gm is the vector of the random effects of interaction of genotype $\times$ year, $g / m$ is the vector of the random effects of triple interaction of genotype $\times$ location $\times$ year, $p$ is the vector of the random effects of plots within locations, and $e$ is the vector of error.

\section{Effect of selection for borer resistance in yield traits and use of selection index}

The data for TRS, TCH, IIB, and TSH in the experiment of Iturama $(2015,2016$, and 2017) were used to assess the effects of selection for borer resistance on yield traits and use of the selection index. The genotypic values for each trait were estimated using the model $y=X m+Z g+W p+T i+e$, as previously described.

The direct and indirect genetic gains were estimated by the following formulas:

$$
\begin{aligned}
& G G_{i} \%=\left(X_{S i}-X_{0 i}\right) \times 100 / X_{0 i} \\
& G G_{j(i)} \%=\left(X_{S j(i)}-X_{0(i)}\right) \times 100 / X_{0 \mathrm{j}}
\end{aligned}
$$

Where, $G G_{i}$ is the genetic gain for trait $i$ by direct selection for the trait $i ; X_{S i}$ is mean of individuals selected for trait $i$; $X_{0 i}$ is the grand mean of the population for trait $i ; G G_{j(i)}$ is the indirect genetic gain for character $j$, by selection for the trait $i ; X_{S j(i)}$ is the mean of trait $j$ in the individuals selected for the trait $i$; and $X_{0 j}$ is the grand mean of the population for trait $j$.

The additive index was simultaneously used to select the genotypes for IIB, TCH, and TRS. The genotypic values predicted by BLUP were used to create the selection index.

The index coefficients for the genotypes were estimated by the formula:

$$
I=(p \times T C H) \times(G V \times T C H)+(p \times T R S) \times(G V \times T R S)+(p \times I I B) \times(G V \times T C I I B H)
$$

Where: $p=$ economic weight (genetic standard deviation) and GV = genotypic value of the trait (Pedrozo et al. 2009). The efficiency of the selection index was obtained using the coincidence coefficient of selected genotypes by the index with the genotypes selected for TSH, which is the main sugar yield trait (Pedrozo et al. 2009).

\section{RESULTS AND DISCUSSION}

\section{Genetic parameters and comparison of selection scenarios for borer resistance}

The mean infestation by borer varied among years $(11.54,4.14$, and $6.75 \%$ of bored internodes, respectively, in 2015 , 2016, and 2017), which was likely related to environmental factors. The natural infestation pressure by the borer had a significant effect on the assessment of genetic variability in the population for borer resistance and on the experimental precision. For instance, the genetic variance was not significant in 2016 in the experiment in Iturama, when the infestation index by borer (IIB) was low (6.37\%), but it was significant in 2015 and 2017, where infestation indexes were higher (13.85 and 9.22\%, respectively) (Table 2). To overcome this issue, the sugarcane breeding program of the USDA (United States Department of Agriculture) commonly enhances borer pressure with an adjacent planting of maize (Zea mays L.), which is artificially inoculated with borer larvae and insecticides are applied to control natural enemies of the borer 
Table 2. Genetic parameters for infestation index by $D$. saccharalis in individual experiments and three selection scenarios

\begin{tabular}{|c|c|c|c|c|c|c|c|c|}
\hline \multirow{2}{*}{ Estimates } & \multicolumn{3}{|c|}{ First year (2015) } & \multicolumn{3}{|c|}{ Second year (2016) } & \multicolumn{2}{|c|}{ Third year (2017) } \\
\hline & Itapagipe & Iturama & Ituiutaba & Itapagipe & Iturama & Tupaciguara & Iturama & Tupaciguara \\
\hline$\sigma_{g}^{2}$ & 2.22 & $4.93^{*}$ & $13.88^{* *}$ & 0.02 & 0.97 & $1.15^{*}$ & $4.50 * *$ & 0.06 \\
\hline$\sigma^{2}$ & 8.95 & 17.62 & 15.72 & 1.94 & 9.91 & 5.1 & 9.53 & 5.19 \\
\hline$\sigma_{p}^{2}$ & 11.17 & 22.55 & 29.6 & 1.96 & 10.87 & 6.25 & 14.03 & 5.25 \\
\hline$h_{g m}^{2}$ & 0.5 & 0.58 & 0.78 & 0.04 & 0.33 & 0.53 & 0.7 & 0.05 \\
\hline Ac & 0.71 & 0.76 & 0.88 & 0.19 & 0.57 & 0.73 & 0.84 & 0.19 \\
\hline$G G(\%)$ & ND & -14.52 & -28.82 & ND & ND & -23.10 & -16.79 & ND \\
\hline
\end{tabular}

\begin{tabular}{lccc} 
& One location ${ }^{1}, \mathbf{3}$ years $^{2}$ & Three locations $^{3}, \mathbf{1}$ year $^{4}$ & Four locations $^{5}, \mathbf{3}$ years $^{-}$ \\
\hline$\sigma_{g}^{2}$ & $2.18^{*}$ & $5.86^{* *}$ & $1.80^{* *}$ \\
$\sigma_{g y}^{2}$ & 1.28 & - & 0.47 \\
$\sigma_{g l}^{2}$ & - & 1.87 & 0.63 \\
$\sigma_{g y l}^{2}$ & - & - & 0.77 \\
$\sigma^{2}$ & 12.2 & 14.6 & 9.18 \\
$\sigma_{p}^{2}$ & 15.82 & 22.34 & 14.69 \\
$h_{g m}^{2}$ & 0.63 & 0.74 & 0.80 \\
$A c$ & 0.77 & 0.86 & 0.89 \\
$r_{g y}$ & 0.63 & - & 0.79 \\
$r_{g l}$ & - & 0.76 & 0.74 \\
$r_{g y l}$ & - & & 0.49 \\
$M e a n$ & 9.81 & 11.82 & 7.63 \\
$G G(\%)$ & -8.89 & -16.82 & -14.17 \\
\hline
\end{tabular}

$\sigma^{2}=$ Genetic variance, $\sigma^{2}=$ Residual variance, $\sigma^{2}=$ Phenotypic variance, $h^{2}=$ Heritability of genotypic mean, $A c=$ Accuracy of selection by genotypic mean, $C V=$ Coefficient of residual variance, $G G=$ Genetic gain, considering $20 \%$ of genotypes selected, $\sigma_{g y}^{2}=$ Variance of genotype $\times$ year interaction, $\sigma_{g l}^{2}=$ Variance of genotype $\times$ location interaction, $\sigma_{g y l}^{2}=$ Variance of genotype $\times$ year $\times$ location triple interaction, $r_{g y}=$ Genotypic correlation between years, $r_{g l}=$ Genotypic correlation between locations, $r_{g y l}=$ Genotypic correlation among locations and years, ND $=$ Non-determined. ${ }^{g y}$ Significant at $P<0.05$ and ${ }^{* *}$ Significant at $P<0.01$, according to deviance analysis. ${ }^{1}$ Iturama, ${ }^{2} 2015$, 2016, and 2017, ${ }^{3}$ Iturama, Itapagipe, and Ituiutaba, ${ }^{4} 2015,{ }^{5}$ Iturama, Itapagipe, and Ituiutaba in 2015, Iturama, Itapagipe, and Tupaciguara in 2016, and Iturama and Tupaciguara in 2017.

(White et al. 2001). However, an artificial infestation is not recommended in experiments located in field areas of mills because of the risk of infesting commercial crop areas. In this case, selection for borer resistance must be performed in locations and years with high natural infestations.

The individual analysis of the experiments demonstrated that the genotypic variance was significant in four of eight experiments, indicating a difference among genotypes in borer resistance (Table 2 ). The genetic gain of selection ( 20\% of genotypes selected) varied from 14.42 to 28.82 , which is considered to be high.

In the analysis of the IIB in the three studied selection scenarios, the genotypic variances for genotype $\times$ year, genotype $\times$ location, and genotype $\times$ year $\times$ location interactions were not significant (Table 2). In addition, the genotypic correlations between years, locations, and year $\times$ location combinations were high, indicating a high consistency in genotype classification among environments (years or locations). White et al. (2001) examined the resistance of sugarcane families to $D$. saccharalis and found no significant family $\times$ year interaction. Previous studies also indicated no significant genotype $\times$ location interaction in sugarcane resistance to $D$. saccharalis (Milligan et al. 2003) and the spotted borer $C$. sacchariphagus (Nibouche and Tibere 2008). However, our h appeared to be the first to consider the genotype $\times$ location $\times$ year triple interaction. In all studied selection scenarios, the genotypic variance was significant, which fosters the achievement of genetic gains for borer resistance (Table 2).

The broad-sense heritability for IIB in individual experiments where the genotypic variance was significant or in the studied selection scenarios were moderate to high and relatively similar $\left(0.53<h^{2}<0.78\right)$. These heritabilities were close to that reported by Milligan et al. (2003) for the infestation index by $D$. saccharalis $\left(h^{2}=0.62\right)$ and to the value 
found by Nibouche and Tibere (2008) for the infestation index by the spotted borer $C$. sacchariphagus $\left(h^{2}=0.80\right)$. The high heritabilities enabled the acquisition of satisfactory genetic gains by selecting for borer resistance $(28.82 \%<G G$ $<8.89 \%$ ) (Table 2).

The coincidence of genotypes selected for borer resistance was high among the individual experiments (Table 3) and selection scenarios (Table 4). For instance, the genotypes RB047050, RB047226, RB047055, RB047212, RB047201, and RB047258, which were selected considering the most complete selection scenario (four locations and 3 years) were selected in most of the situations, confirming high consistence among the experiments.

The accuracy of predicting genotypic values for the genotype in single experiments was high $(A c>0.70)$ (Table 3 ). On the other hand, the accuracy of predicting genotypic values for the IIB in several locations depended on the number of locations where the clone was present. The accuracies for the genotype present at only one location were relatively low $(A c<0.70)$, whereas the accuracies for the genotype present in at least two locations were high $(A c>0.70)$ (Table 4).

Overall, because of the non-significant effect of genotype $x$ environment (location or year) interaction in the sugarcane resistance to borer, the genotypes could be selected for borer resistance in a single experiment or by means of experiments in several locations. The selection in a single location in 1 year is advantageous because of the cost effectiveness of the borer damage assessment because it is a field based and labor-intensive task, as highlighted by Milligan et al. (2003). However, the genotypes that advance to the experimental stages of a sugarcane breeding program are often not planted in all locations of the experimental network because of technical issues, such as the lack of propagation material or field area. The selection in a single location could exclude several genotypes from selection for borer resistance. In this case, the genotypes could be selected by means of an infestation index in all assessed locations. This practice could enable

Table 3. Genotypic values of sugarcane genotypes for infestation index by borer (IIB\%) in individual experiments

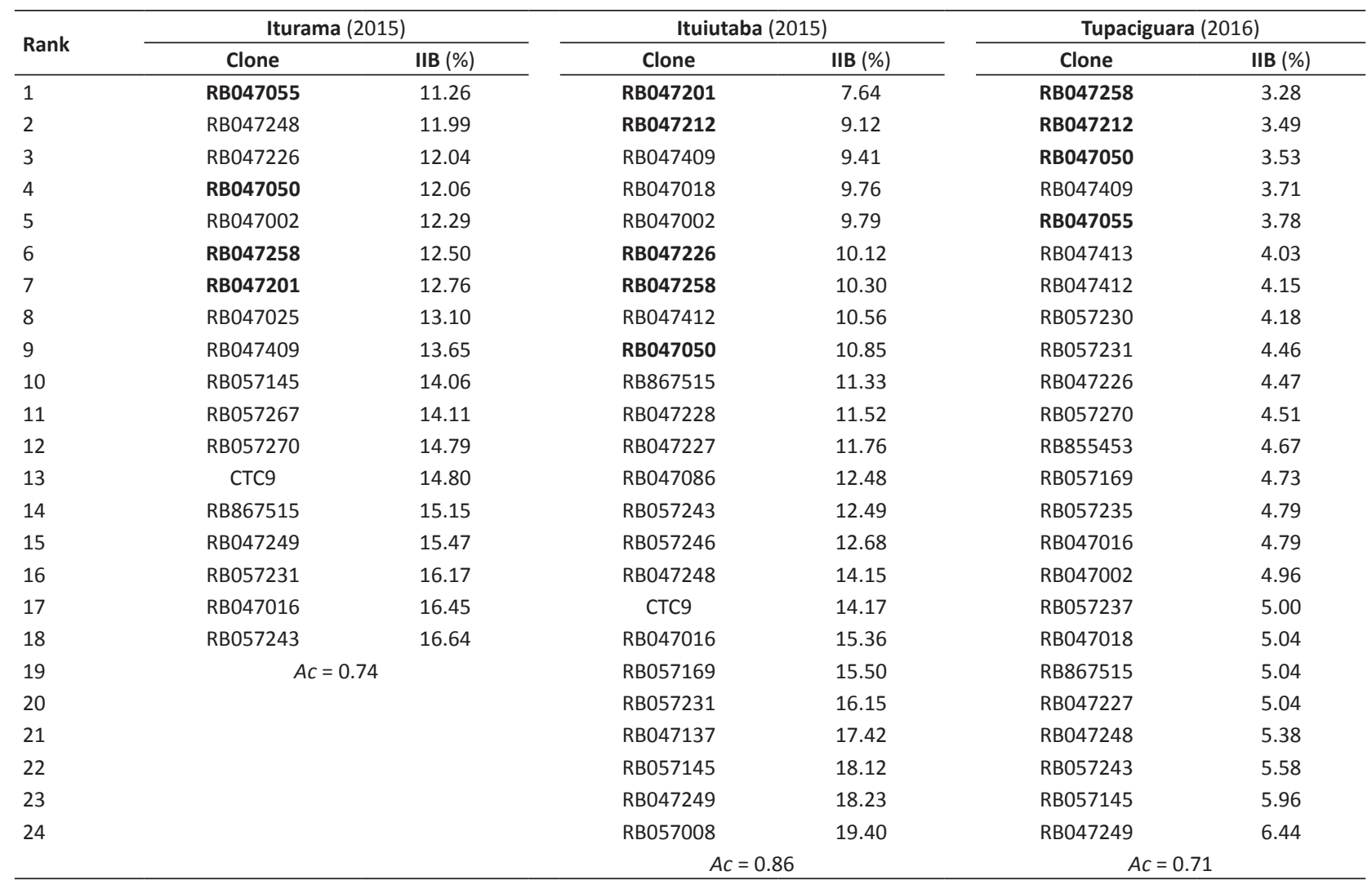

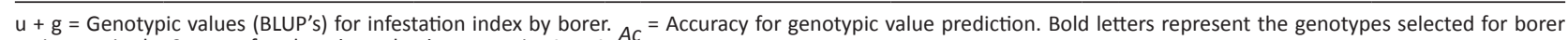
resistance in the 3 year - four location selection scenario. Ac = Accuracy. 
accurate prediction of the resistance of all the genotypes to the sugarcane borer, especially the genotypes assessed in more than one location.

\section{Effects of the selection for borer resistance on yield traits and use of the selection index}

The yield traits assessed to select sugarcane genotypes usually present a significant genotype $\times$ location interaction (Bastos et al. 2007, Silveira et al. 2012). Therefore, the study of the effect of selection for borer resistance in yield traits and the use of the selection index was performed at only one location. The TCH, TRS, and TSH were analyzed based on data from the experiment in Iturama during 2015, 2016, and 2017. The analyses showed that there was no genotype $\times$ year interaction for any trait and genotypic variance was significant for all traits (Table 5 ). Therefore, genetic gains of selection could be obtained for all traits.

Table 4. Genotypic values of sugarcane genotypes for infestation index by borer (IIB) in three selection scenarios

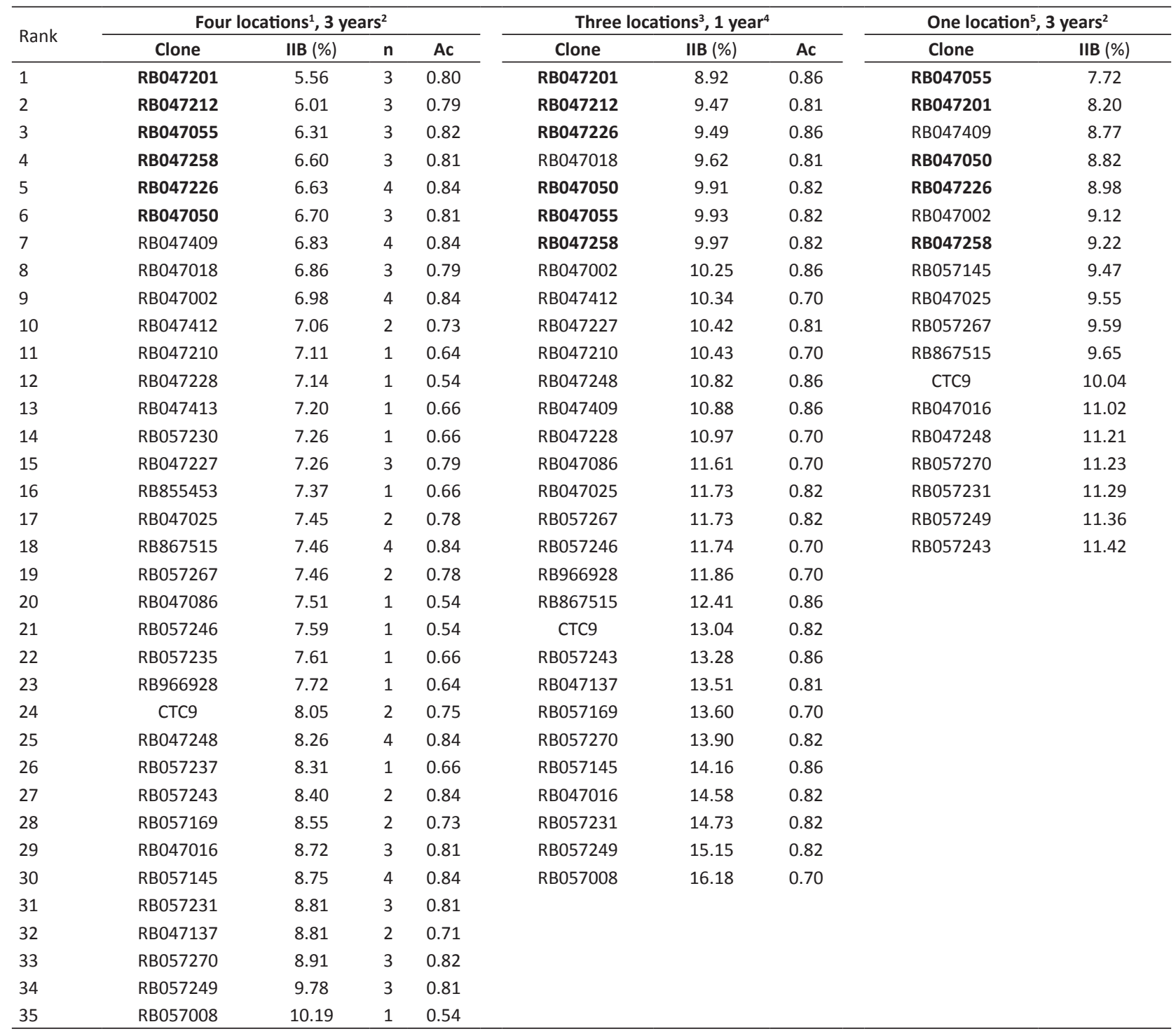

Ac = Accuracy for genotypic value prediction. ${ }^{1}$ Iturama, Itapagipe, and Ituiutaba in 2015, Iturama, Itapagipe, and Tupaciguara in 2016 , and Iturama and Tupaciguara in 2017. ${ }^{2} 2015,2016,2017 .{ }^{3}$ Iturama, Itapagipe, and Ituiutaba. ${ }^{4} 2015 .{ }^{5}$ Iturama. Bold letters represent the genotypes selected for borer resistance in the 3 year - four location selection scenario. ${ }^{*} \mathrm{n}$ is the number of experiments in which the clone was present. 
Even though the selection of the sugarcane genotypes for infestation index provided considerable genetic gains for borer resistance, the indirect genetic gain in TRS, TCH, and especially TSH were much lower than would be obtained by direct selection for each trait, with some even exhibiting negative values (Table 5). The selection for only borer resistance may result in genotypes with unfavorable traits and lower sugar yield (White et al. 2006, White et al. 2011). Therefore, the use of the selection index was justified.

The use of selection index using IIB, TRS, and TCH enabled the acquisition of high genetic gains for all traits, providing values close to those that would be obtained by direct selection for each trait (Table 5). In addition, there was a high coincidence between the genotypes selected by the selection index and the genotypes selected for TSH (coincidence coefficient $=83.33 \%$ ), which is the main trait targeted in sugarcane breeding and reflects the yield of the main product of the sugarcane crop. We highlighted the consistency of the selection index by the fact that the control variety RB867515, which is known to have high borer resistance level (Ferreira et al. 2018) and high TBH (Bastos et al. 2007, Silveira et al. 2012), was selected using the designed selection index.

Indeed, as the genotypes used in this study composed the most advanced stage of RIDESA's breeding program, they underwent several selection steps and had favorable agronomic traits, which created potential varieties could be

Table 5. Genetic parameters, genotypic values, and direct and indirect genetic gains by direct selection for each trait, selection for borer resistance, and selection using the selection index for tons of cane per hectare (TCH), theoretical recoverable sugar (TRS), infestation index by borer (IIB), and tons of sugar per hectare (TSH)

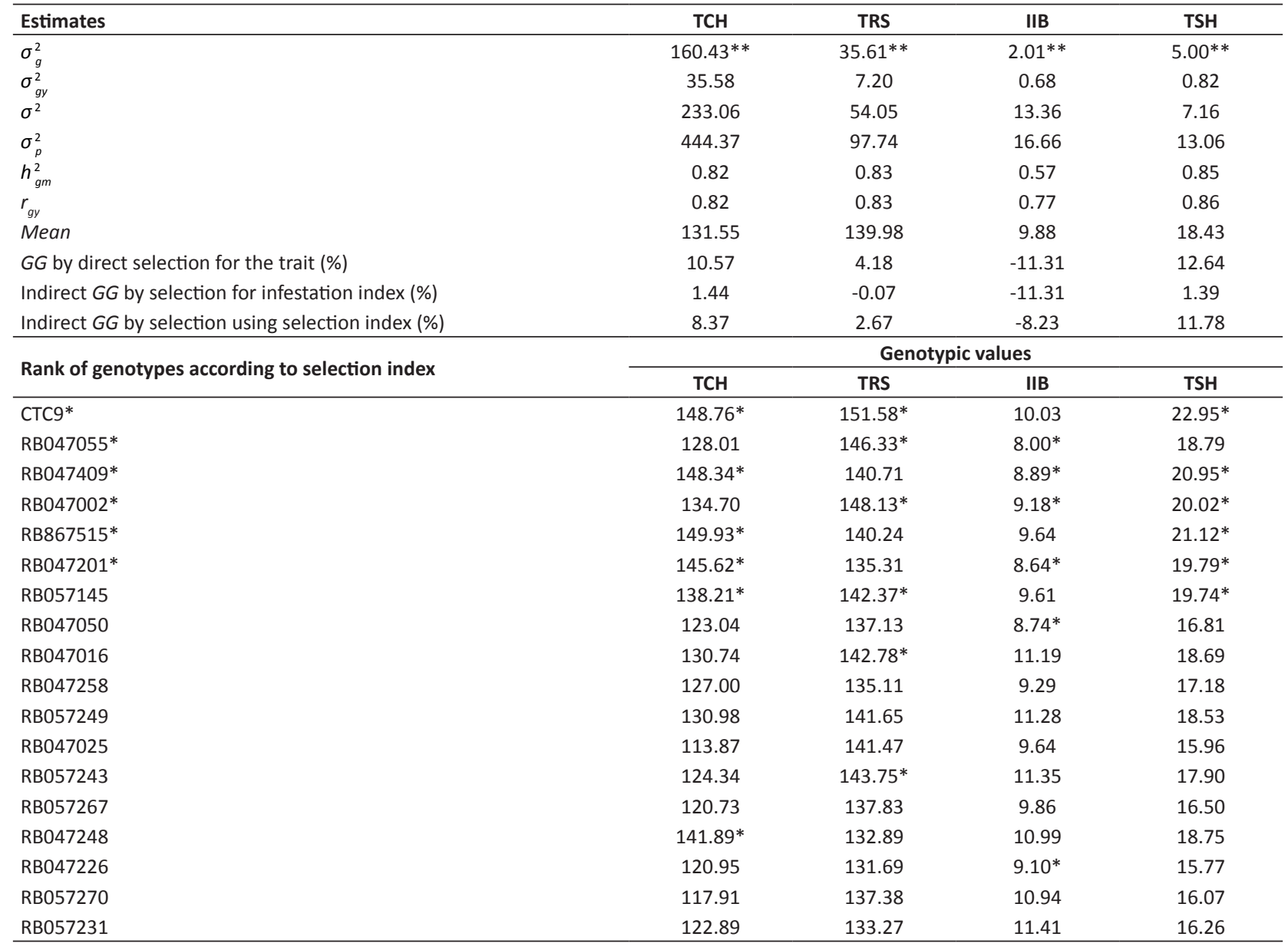

$\sigma_{g}^{2}=$ Genotypic variance, $\sigma_{g y}^{2}=$ Variance of genotype $\times$ year interaction, $\sigma^{2}=$ Residual variance, $\sigma_{p}^{2}=$ Phenotypic variance, $h_{g m}^{2}=$ Heritability for genotypic mean, $r_{g y}=$ Genotypic correlation among years, $G G=$ genetic gain, considering an $\sim 20 \%$ of genotypes selected, ${ }^{p} *$ Significant at $P<0.01$, according to deviance analysis. ${ }^{1 *}$ Genotypes selected by direct selection for the respective trait. 
recommended to the growers. The most resistant of these genotypes could be readily recommended for locations with higher borer pressure if they combine borer resistance with other favorable agronomic traits, such as high sugar yield.

\section{CONCLUSIONS}

The borer population influences both genotypic variance and heritability; thus, it is necessary to select sugarcane clones for borer resistance in areas with high natural borer infestation to achieve suitable genetic gains.

The genotypes could be selected either in a single location and single year or through genotypic means in several locations, years, or location and year combinations.

Selection for borer resistance reduces the genetic gains for TCH, TRS, and TSH. However, the use of the selection index combining IIB with TCH and TRS may enable the selection of genotypes with considerable both borer resistance and sugar yield.

\section{ACKNOWLEDGEMENTS}

We thank the technical assistance provided by the Inter-University Network for the Development Sugarcane Industry in Brazil (RIDESA). The financial support provided by the National Council of Scientific and Technological Development (CNPq), CAPES Foundation (Brazilian Ministry of Education), the Minas Gerais State Foundation for Research Aid (FAPEMIG).

\section{REFERENCES}

Bastos IT, Barbosa MH, Resende MD, Peternelli LA, Silveira LC, Donda L, Fortunato AA, Costa PM and Figueiredo IC (2007) Avaliação da interação genótipo $x$ ambiente em cana-de-açúcar via modelos mistos. Pesquisa Agropecuária Tropical 37: 195-203.

Bessin RT, Reagan TE and Martin FA (1990) A moth production index for evaluating sugarcane cultivars for resistance to the sugarcane borer (Lepidoptera: Pyralidae). Journal of Economic Entomology 83: 221-225.

CONAB (2019) Companhia nacional de abastecimento. Acompanhamento da safra brasileira: cana-de-açúcar. Available at <https://www.conab. gov.br/info-agro/safras/cana/boletim-da-safra-de-cana-de-acucar>. Accessed on Sept 2, 2019.

Consecana (2006) Manual de instruções Consecana - SP. $5^{\text {a }}$ edição. Consecana, Piracicaba, 112p.

Cristofoletti PT, Kemper EL, Capella AN, Carmago SR, Cazoto JL, Ferrari F, Galvan TL, Gauer L, Monge GA, Nishikawa MA and Santos NZ (2018) Development of transgenic sugarcane resistant to sugarcane borer. Tropical Plant Biology 11: 17-30.

Ferreira CA, Santana MV, Santos JB, Santos TT, Lôbo LM and Fernandes PM (2018) Yield and technological quality of sugarcane cultivars under infestation of Diatraea saccharalis (Fabr., 1794). Arquivos do Instituto Biológico 85: 1-7.

Francischini FJ, Campos JB, Alves-Pereira A, Viana JP, Grinter CC, Clough SJ and Zucchi MI (2017) Morphological and molecular characterization of Brazilian populations of Diatraea saccharalis (Fabricius, 1794) (Lepidoptera: Crambidae) and the evolutionary relationship among species of Diatraea Guilding. PloS One 16: 1-24.

Gazaffi R, Cursi DE, Chapola RG, Santos JM, Fernandes-Jr AR, Carneiro MS, Barbosa GV and Hoffmann HP (2016) RB varieties: a major contribution to the sugarcane industry in Brazil. Proceedings of the International Society of Sugar Cane Technologists 29: 1677-1682.

Girón-Pérez K, Oliveira AL, Teixeira AF, Guedes RNC and Pereira EJG (2014) Susceptibility of Brazilian populations of Diatraea saccharalis to Cry $1 \mathrm{Ab}$ and response to selection for resistance. Crop Protection 62: 124-128.

MAPA - Ministério da Agricultura, Pecuária e Abastecimento (2019) Registro Nacional de cultivares. Available at <http://sistemas. agricultura.gov.br/snpc/cultivarweb/cultivares_registradas.php $>$. Accessed on Septe 2, 2019.

Milligan SB, Balzarini M and White WH (2003) Broad-sense heritabilities, genetic correlations, and selection indices for sugarcane borer resistance and their relation to yield loss. Crop Science 43: 1729-1735.

Nibouche S and Tibere R (2008) Damage assessment for selection of resistance to the spotted stalk borer and genetic correlations for resistance and yield components in sugarcane. Plant Breeding 127: 38-42.

Nikpay A (2016) Evaluation of varietal resistance of commercial sugarcane varieties to stalk borers, Sesamia spp. (Lepidoptera: Noctuidae), under field conditions. Acta Entomológica Sinica 57: 785-790.

Pedrozo AC, Benites FR, Barbosa MH, Resende MD and Silva FL (2009) Eficiência de índices de seleção utilizando a metodologia REML/BLUP no melhoramento da cana-de-açúcar. Scientiae Agraria 10: 31-36.

Pimentel GV, Tomaz AC, Brasileiro BP, Peternelli LA and Barbosa MHP (2017) Oviposition preference and larval performance of sugarcane borer in eight sugarcane genotypes. Ciência e Agrotecnologia 41: 439-446.

Resende MD (2016) Software Selegen-REML/BLUP: a useful tool for plant breeding. Crop Breeding and Applied Biotechnology 16: 330-339.

Simões RA, Feliciano JR, Solter LF and Delalibera Jr I (2015) Impacts 


\section{AC Tomaz et al.}

of Nosema sp. (Microsporidia: Nosematidae) on the sugarcane borer, Diatraea saccharalis (Lepidoptera: Crambidae). Journal of invertebrate pathology 129: 7-12.

Silveira LC, Kist V, Paula TO, Barbosa MH, Oliveira RA and Daros E (2012) Adaptabilidade e estabilidade fenotípica de genótipos de cana-deaçúcar no estado de Minas Gerais. Ciência Rural 42: 587-593.

Tomaz AC, Coutinho AE, Soares BO, Peternelli LA, Pereira EJG and Barbosa MHP (2017) Assessing resistance of sugarcane varieties to sugar cane borer Diatraea saccharalis Fab. (Lepidoptera: Crambidae). Bulletin of Entomological Research 108: 547-555.

Tomaz AC, Wartha CA, Resende MD, Brasileiro BP, Peternelli LA and Barbosa MHP (2019) Genetic parameters and selection of sugarcane in early selection stages for resistance to sugarcane borer Diatraea saccharalis. Crop Breeding and Applied Biotechnology 19: 208-216.

Valente ECN, Broglio SMF, Dias-Pini NS, Micheletti LB, Lima AST and Barbosa T (2018) Selectivity of pesticides to egg parasitoid in sugarcane. Sugar Tech 20: 765-769.
Verissimo MA, Anjos SD, Aires RF, Daros E and Panziera W (2012) Adaptabilidade e estabilidade de genótipos precoces de cana-de-açúcar no Rio Grande do Sul. Pesquisa Agropecuária Brasileira 47: 561-568.

White WH, Miller JD, Milligan SB, Burner DM and Legendre BL (2001) Inheritance of sugarcane borer resistance in sugarcane derived from two measures of insect damage. Crop Science 41: 1706-1710.

White WH (1993) Cluster analysis for assessing sugarcane borer resistance in sugarcane line trials. Field Crops Research 33: 159-168.

White WH, Tew TL and Richard Jr EP (2006) Association of sugarcane pith, rind hardness, and fiber with resistance to the sugarcane borer. Journal of American Society of Sugar Cane Technologists 26: 87-100.

White WH, Hale AL, Veremis JC, Tew TL and Richard EP (2011) Registration of two sugarcane germplasm clones with antibiosis to the sugarcane borer (Lepidoptera: Crambidae). Journal of Plant Registrations 5: 248-253. 